\title{
Processing and Characterization of Yttria-Stabilized Zirconia Foams for High-Temperature Applications
}

\author{
Ana María Herrera, Amir Antônio Martins de Oliveira Jr., \\ Antonio Pedro Novaes de Oliveira, and Dachamir Hotza \\ Graduate Program in Materials Science and Engineering (PGMAT), Departments of Chemical (EQA) and Mechanical Engineering \\ (EMC), Federal University of Santa Catarina (UFSC), 88040-900 Florianópolis, SC, Brazil
}

Correspondence should be addressed to Dachamir Hotza; dhotza@gmail.com

Received 30 September 2013; Accepted 15 November 2013

Academic Editor: Young-Wook Kim

Copyright (c) 2013 Ana María Herrera et al. This is an open access article distributed under the Creative Commons Attribution License, which permits unrestricted use, distribution, and reproduction in any medium, provided the original work is properly cited.

\begin{abstract}
In this work ceramic foams of 3 and $8 \mathrm{~mol} \%$ yttria-stabilized zirconia (3YSZ and 8YSZ) were manufactured by the replication method using polystyrene-polyurethane foams with pore sizes in the 7-10 ppi range. A second coating was carried out on presintered foams in order to thicken struts and hinder microstructural defects. The produced ceramic foams were structurally and thermomechanically characterized. Samples recoated with 3 YSZ presented the highest relative densities $(0.2 \pm 0.1)$ which contributed to a better mechanical and thermal behavior.
\end{abstract}

\section{Introduction}

Porous radiant burners are devices used in applications benefit from radiant thermal heating. Numerous industries employ this technology for firing and drying, lower pollutant emission, and better product quality reached with these burners $[1,2]$.

Other functional advantages are a higher flame velocity within the porous structure when compared to a laminar free flame (due to the preheated of reagents), higher turn-down ration, higher efficiency in heat transfer by radiation, and the possibility of burning low calorific value fuels or very lean mixtures [3].

Ceramics foams for porous radiant burners are mainly produced by the replication method from polymeric templates. The method consists in the impregnation of a polymeric sponge with a ceramic slurry followed by a heat treatment which leads to the burning out of the organic body (sponge) and to the sintering of the ceramic skeleton [4]. Along the manufacture process, there are key parameters that must be taken into account to ensure the final product effectiveness. Among them, the most important are the linear expansion coefficient, maximum working temperature and thermal shock resistance of the ceramic material, thixotropy and pseudoplasticity of the ceramic slurry, and, finally, the heating rate of the thermal treatment. According to the above, the most reliable ceramic materials to work with are cordierite, mullite, silicon carbide, alumina, partially stabilized zirconia (YSZ), and some composite systems [5-13].

Cellular ceramics are already commercially available for a wide range of technological applications including filters, membranes, catalytic substrates, thermal insulation, gas burner media, refractory materials, and lightweight structural panels [5-7]. In these cases, reticulated porous ceramics are used because of their functional properties, such as low thermal expansion coefficient and thermal conductivity, high permeability, and chemical inertness [7]. Considering the particularities associated with each specific application, reticulated porous ceramics are prepared and consolidated.

Variations of this method employ organic structures, such as wood or cellulose-based materials, as templates for the production of reticulated porous ceramics [3]. The use of a second coating applied to the presintered foams has been reported as a way of enhancing the mechanical resistance due to the thickening of the struts. This procedure hinders microstructural defects that are left in the walls of the ceramic foams during the burning out of the organic components [14$16]$. 
Zirconia has been mentioned among possible candidates as material for high-temperature (for continuous operation above $1600^{\circ} \mathrm{C}$ ) porous burners $[17,18]$. Nevertheless, phase transformations that are dependent on temperature and composition are obstacles to a broader application of this material in radiant burners. Yttria-stabilized zirconia (YSZ) has been developed to hinder allotropic changes among the zirconia phases by replacing zirconium $\left(\mathrm{Zr}^{4+}\right)$ by yttrium ions $\left(\mathrm{Y}^{3+}\right)$ into the zirconia matrix [4]. Monoclinic is the most stable phase at room temperature, but YSZ allows tetragonal and cubic phases to be stable at lower temperatures with enhanced mechanical, thermal, and electrical properties.

The aim of this work was to evaluate the functionality, quality, and thermomechanical strength of 3 and $8 \mathrm{~mol} \%$ yttria-stabilized zirconia (3YSZ or $8 Y S Z$ ), as base materials for the porous radiant burners. From the mechanical point of view, 3YSZ would be the best option, but 8 YSZ was chosen due its high oxygen ion conduction while blocking electronic conduction. This feature makes 8 YSZ the standard electrolyte material for solid oxide fuel cells (SOFC), which must be operated at intermediate to high temperatures (600 to $1000^{\circ} \mathrm{C}$ ). The motivation in this case is to associate a porous burner to a no-chamber SOFC, providing compatibility between both devices [19].

\section{Materials and Methods}

2.1. Materials. The starting materials were $3 \mathrm{YSZ}$ (TZ-3YBE, Tosoh, Japan), with a mean particle size (d50) of $0.45 \mu \mathrm{m}$ and density of $6.05 \mathrm{~g} / \mathrm{cm}^{3}$, and 8YSZ (YSZ8-U1, NexTech, USA) with a mean particle size (d50) of $0.32 \mu \mathrm{m}$ and density of $7.80 \mathrm{~g} / \mathrm{cm}^{3}$. Ammonium polyacrylate (NH4PAA, Darvan, 821-A, Vanderbilt, USA) was used as dispersant and polyvinyl alcohol (PVA, $\left(\mathrm{CH}_{2} \mathrm{CH}(\mathrm{OH})_{n}\right)$, molecular weight: 70-100 g/mol Vetec, Brazil) as binder. To obtain a homogeneous slurry without bubbles, an antifoamer emulsion based on silicone was needed, (Sigma-Aldrich, Brazil).

Finally, for the manufacture of the ceramic foams by the replication method, a polystyrene-polyurethane foam (Crest Foam Industries, USA) with an average pore density of $10 \mathrm{ppi}$ and nominal density of $0.03 \mathrm{~g} / \mathrm{cm}^{3}$ was employed.

2.2. Methods. Ceramic powders were characterized by zeta potential (Zetananosizer, Malvern, USA) and X-ray diffraction (X'pert, PW3710, Phillips, the Netherlands), based on $0.05^{\circ}$ step, $1 \mathrm{~s}$ of step time, and a reading interval of $2 \theta$ from $0^{\circ}$ to $118^{\circ}$. Rheological studies were performed for both $3 \mathrm{YSZ}$ and 8YSZ suspensions. The effect of the solids load, varied between 75 and $77.5 \mathrm{wt} \%$, and binder amount, varied between 3.5 and 4.5 mass\% suspension weight (base: $100 \mathrm{wt} \%$ ), were evaluated. The ceramic foams were manufactured by the replication method. The impregnation step consisted in soaking the compressed sponge into the ceramic suspension and then releasing the tension so that the sponge could absorb as much as possible of the slurry. Subsequently, it is taken out to be wrung and remove all the slurry in excess, followed by a very soft air-spray to open the closed cells. Finally, it is dried under room temperature during $24 \mathrm{~h}$ and then presintered according to the following thermal cycles: $1^{\circ} \mathrm{C} / \mathrm{min}$ from 25 to $200^{\circ} \mathrm{C} ; 0.5^{\circ} \mathrm{C} / \mathrm{min}$ to $600^{\circ} \mathrm{C}$; then $5^{\circ} \mathrm{C} / \mathrm{min}$ to $1150^{\circ} \mathrm{C}$ with a holding time of $2 \mathrm{~h}$. Subsequently, the samples were cooled (at $10-15^{\circ} \mathrm{C} / \mathrm{min}$ ) down to the room temperature.

A second coating was applied (in some cases) with a lighter suspension of the same material (70\% solids, 3.5\% binder). The sintering step was carried out with a heating rate of $7^{\circ} \mathrm{C} / \mathrm{min}$ from room temperature to $900^{\circ} \mathrm{C}$ and $3^{\circ} \mathrm{C} / \mathrm{min}$ to $1600^{\circ} \mathrm{C}$, with a holding time of $2 \mathrm{~h}$, and then samples were cooled (at $10^{\circ} \mathrm{C} / \mathrm{min}$ ) down to room temperature.

The sintered YSZ foams were characterized by its relative density and total porosity, wherein the geometrical density was calculated by measuring the mass and volume of the samples and the solid material density by helium picnometry.

Scanning electron microscopy (SEM, Phillips XL 30, the Netherlands) was used to access the microstructure of foams. Mechanical properties were measured according to usual procedures (compression strength [20], thermal shock resistance [21]). Finally, the foams were tested as porous radiant burners, at a constant fuel/air mixture ratio of 0.9 at different time cycles: $10 \mathrm{~min}^{-1}$ cycle, $10 \mathrm{~min}^{-5}$ cycles, and $360 \mathrm{~min}^{-1}$ cycle.

The mechanical testing was performed in 10 cylindrical samples (diameter equal to height) of sintered YSZ. The load velocity was $0.5 \mathrm{~mm} / \mathrm{s}$, based on the work of Elverum et al., [20] with the aim to compare results and materials. A universal mechanical testing machine was employed (DL2000, EMIC, Brazil).

The thermal shock test consisted in exposing the ceramic foams with a prismatic shape $(170 \times 30 \times 25 \mathrm{~mm})$ at high/low temperatures based on ASTM C1198-96 [22]. The samples were placed into a muffle furnace at $1000^{\circ} \mathrm{C}$ during $15 \mathrm{~min}$ and taken out and immediately cooled by forced air (hair dryer) to room temperature. This procedure was repeated 4, 8, and 12 times. The loss of the mechanical properties caused by the induced thermal shock was verified by measuring Young's modulus. This parameter was measured by a nondestructive method, submitting the ceramic foam to an impulse which excites the natural vibration frequencies of the structure. Young's modulus is related to the natural frequency, geometric dimensions, and mass of the ceramic foam sample by

$$
E=0.9465 \cdot\left(\frac{m \cdot f_{f}^{2}}{b}\right) \cdot\left(\frac{L^{2}}{t^{2}}\right) \cdot T_{1},
$$

where

$E$ is the Young modulus,

$m$ is the sample mass,

$b, L, t$ are the width, the length, and the thickness of the sample, respectively,

$f_{f}$ is the fundamental frequency, and

$T_{1}$ is the correction factor related to the fundamental flexional mode. 


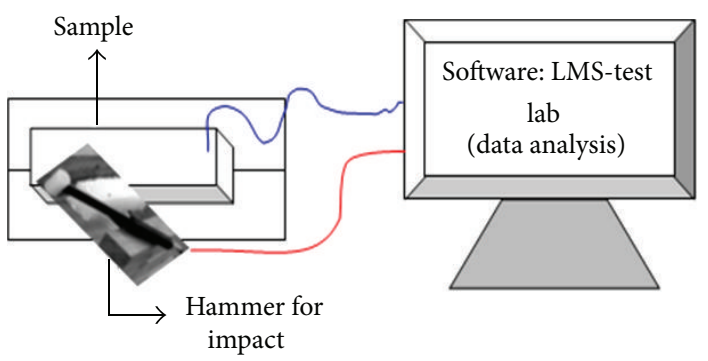

FIGURE 1: Dynamic test for identifying the structure's Young modulus.

The total damage in the ceramic structure due to the thermal shock may be estimated from

$$
D_{E}=1-\frac{\sigma_{c}}{\sigma_{0}} \approx 1-\frac{E_{f}}{E_{0}},
$$

where

$D_{E}$ is the total damage factor, from 0 to 1 ,

$E_{f}$ is the last calculated Young modulus,

$F_{f}$ is the last calculated mechanical strength,

$E_{0}$ is the initial Young modulus, and

$\sigma_{0}$ is the initial calculated mechanical strength.

The chart in Figure 1 represents the above-described thermal shock test.

An experimental test with the ceramic foams as porous burners was performed. The test employed disk shaped samples, with $35 \mathrm{~mm}$ diameter and $35 \mathrm{~mm}$ thickness, fitted inside a steel tube using a fiber mat to thermally insulate the ceramic foams from the tube wall. The burner was fed with a natural gas and air mixture with fuel equivalence ratio of 0.9 . The flame, after approximately 2-3 min after ignition, was stabilized within the porous matrix. The outlet surface of the burner was allowed to radiate heat freely to the external ambient. The burner was submitted to periods of continuous operation of $10 \mathrm{~min}$ and $6 \mathrm{~h}$. The adiabatic flame temperature corresponding to this equivalence ratio is approximately $2150 \mathrm{~K}$ [23]. This high operation temperature was specified with the aim to test the intrinsic properties of the YSZ samples.

The double-coated 3 YSZ samples worked at the specified equivalence rate and with a flame velocity of $15 \mathrm{~cm} / \mathrm{s}$, as shown in Figure 2.

\section{Results and Discussions}

3.1. X-Ray Diffraction. Figure 3 shows the X-ray diffractograms obtained for the zirconium powders. As expected, 3YSZ (Figure 3(a)) corresponds mainly to the tetragonal phase, with a minor presence of monoclinic phase, which may be seen as little isles in the tetragonal matrix, which might contribute to a higher fracture toughness to the material [24]. For 8YSZ (Figure 3(b)), sharp peaks correspondent to the cubic phase were detected, as expected. This phase is known to present a characteristic grain growth, which reduces the mechanical resistance of the material [25].

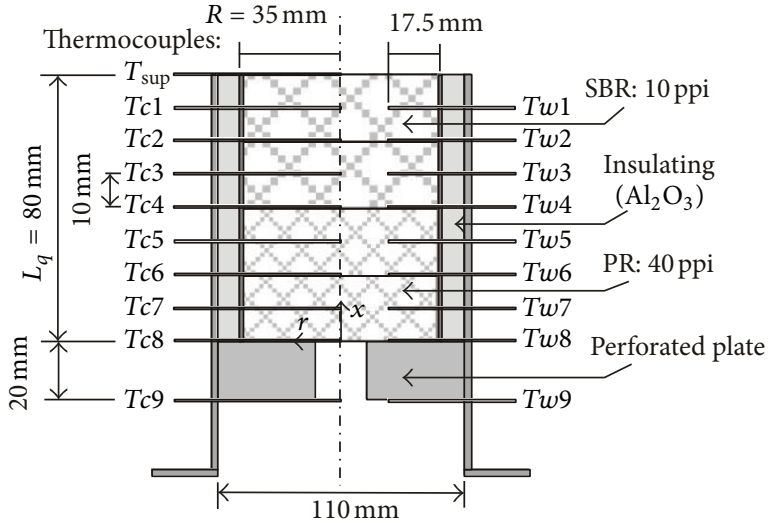

FIGURE 2: Setup of the porous burner test at a lab scale.

3.2. Rheological Characterization. The effect of the dispersant on the isoelectric point (IEP) of the materials was evaluated. In Figure 4 it is shown how the $\mathrm{pH}$ at the IEP is shifted from the basic to the acid range. The $3 \mathrm{YSZ}$ suspension has its original IEP at $\mathrm{pH} 6.9$, the value that converges with the ones found in the literature, [26, 27], this IEP was fell in the range of 5.2 to 7.2. Adding one drop of dispersant to the solution, the IEP was then located at a $\mathrm{pH}$ 2.9. The same feature might be observed for the $8 \mathrm{YSZ}$ suspension. IEP is originally at $\mathrm{pH} 7.5$, the value which converges with the IPE's of 8 YSZ powder (Sigma-Aldrich) at 9.2 and the $8 Y S Z$ powder (Innovano) at 7.2. Adding a dispersant drop, the IEP moves to 3.2. This phenomenon is attributed to the change of the electrochemical properties of the particles surface when the dispersant particles are attached to them $[26,27]$.

Four formulations were analyzed for each material, as previously described. The guide parameters were the pseudoplasticity and thixotropy, rheological properties that should be present in any suspension to be applied in the replica method. A high viscosity is desired at low shear stress and a low viscosity when at high shear stress. This ensures, respectively, that the slurry will flow into the reticulated structure by the impregnation, and, when at rest, the slurry will be strongly adhered to the polymeric walls. A high thixotropy (large area between the flow curves) corresponds to the facility that the slurry will recover its initial viscosity after the impregnation process $[28,29]$. Figure 5 shows the thixotropy graphs of both systems, where those two properties can be observed. Figure 5(a) corresponds to the 3YSZ suspensions with $77.5 \%$ 


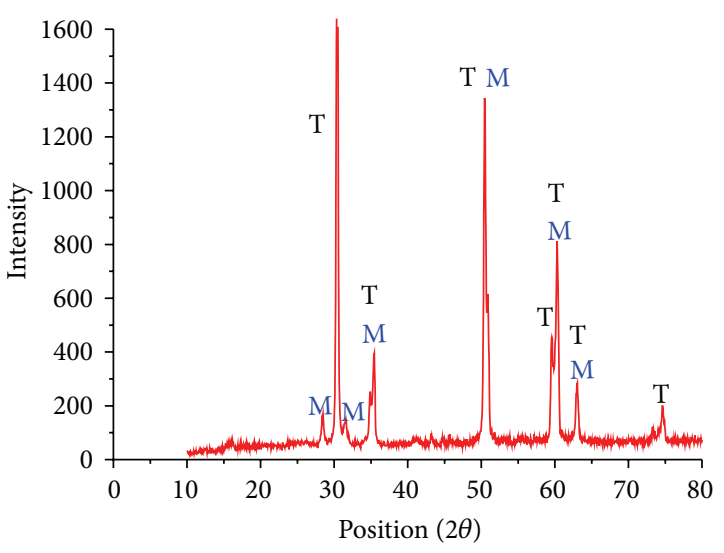

T Tetragonal phase M Monoclinical phase

(a)

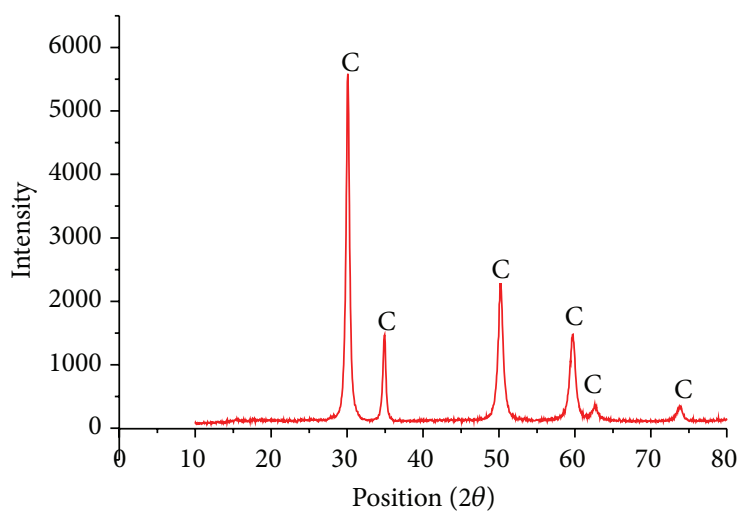

C Cubic phase

FIGURE 3: X-ray diffraction of the YSZ powders after sintering: (a) 3YSZ; (b) 8YSZ.

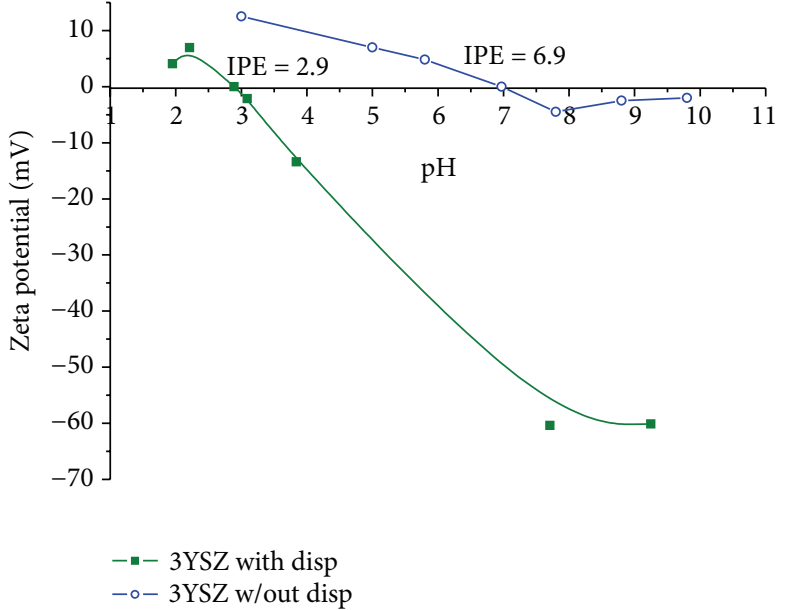

(a)

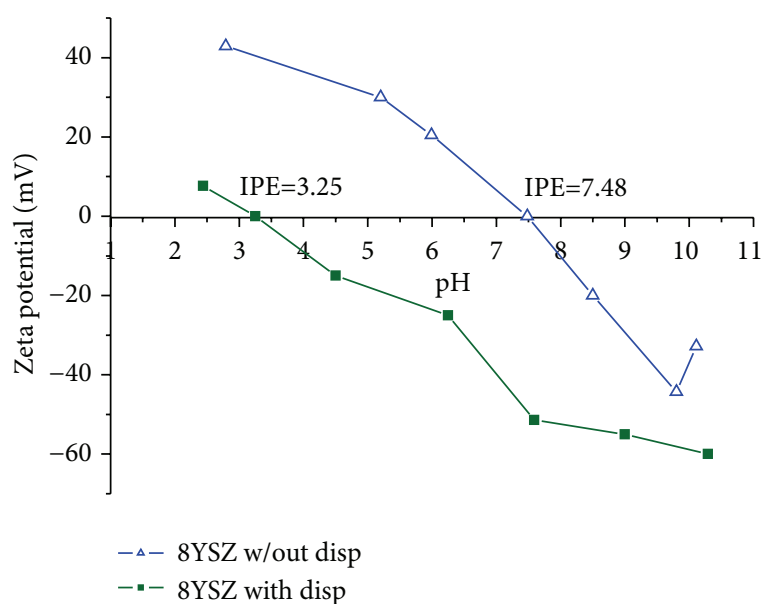

(b)

FIGURE 4: Zeta potential of zirconia suspensions as a function of $\mathrm{pH}$ and added dispersant. (a) 3YSZ; (b) 8 YSZ.

solids and $3.5 \%$ binder. In the case of 8 YSZ (Figure 5(b)), the formulation with $77.5 \%$ solids and $4.5 \%$ binder was selected. The maximum amount of solids is naturally desired $[3,14,27$, 30].

In Figure 5 the thixotropy curves present different behaviors. The steeper the curve, the higher the viscosity at high shear stress and consequently the higher the initial viscosity [15]. Those characteristics provide a thicker layer when coating and, consequently, higher homogeneity and better densification of the material [14].

3.3. Physical Characterization of Foams. Relative density and porosity were determined for the three classes of yttriastabilized zirconia foams produced, Table 1.

Higher relative density values were obtained for double coated 3 YSZ in comparison to single-coated 3 YSZ and 8YSZ.
This result is a consequence of the slightly larger amount of solids in the cellular structure, which also affects the porosity of the ceramic foam.

Images obtained by SEM allow for having an overall view of the foam structures obtained. Figure 6 presents the different types of foams manufactured. Figures 6(a) and 6(b) correspond to single-coated $3 \mathrm{YSZ}$ and $8 \mathrm{YSZ}$, respectively. Homogeneous surfaces with few microstructural defects are observed, as micropores inside the struts and minicracks. Figure 6(c) corresponds to a double-coated 3YSZ foam showing how the internal surfaces have more micropores and microcracks than the external walls. Moreover, the vertices are rounded after the recoating, which might enhance the mechanical strength of the structure [14]. Figure 6(d) shows typical defects, characteristic of the replica method. Nevertheless, the thicker walls obtained with a recoating are seen, as well. 


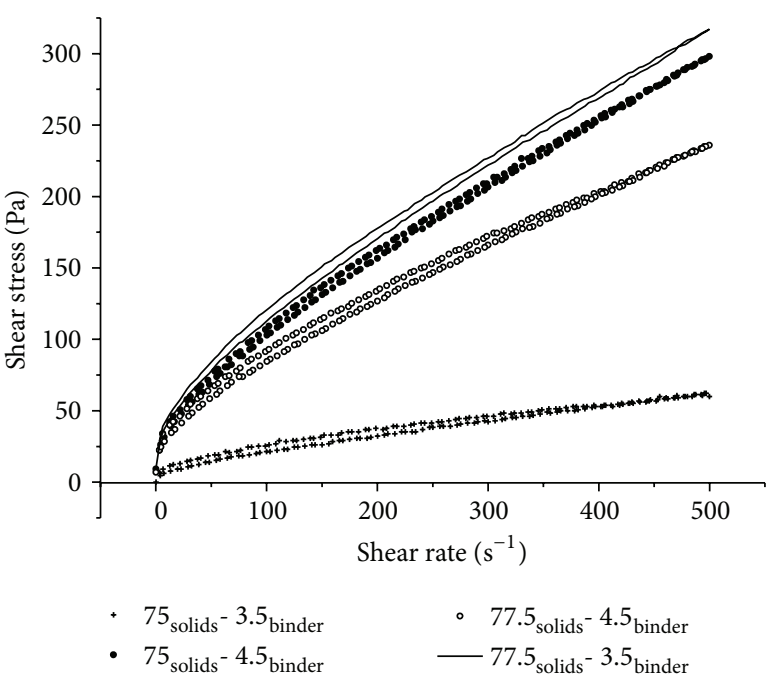

(a)

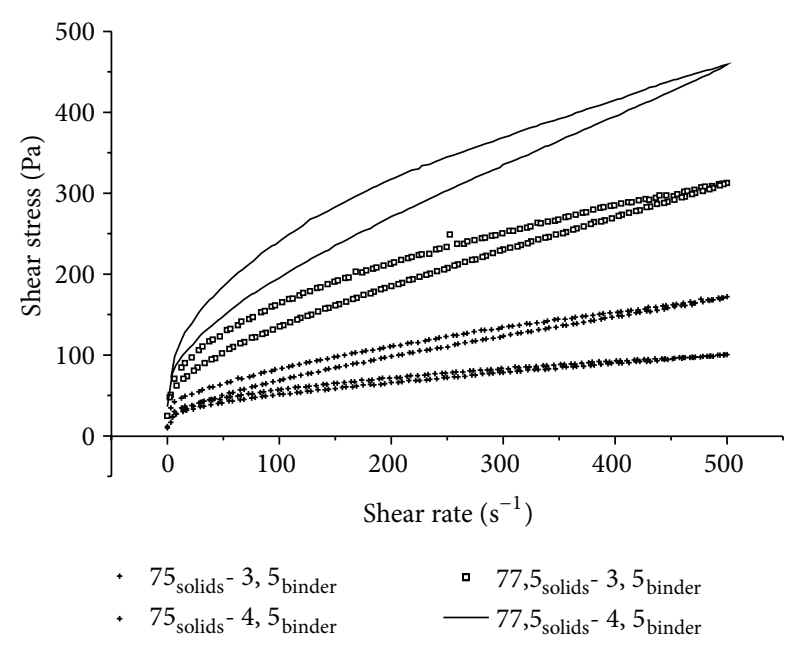

(b)

FIGURE 5: Rheogram of the ceramic slurries: (a) 3YSZ; (b) 8YSZ, for different solid and binder concentrations.

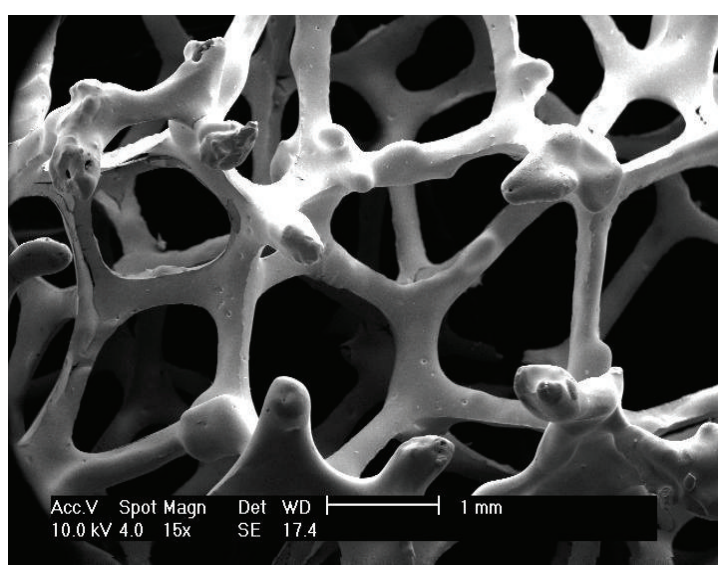

(a)

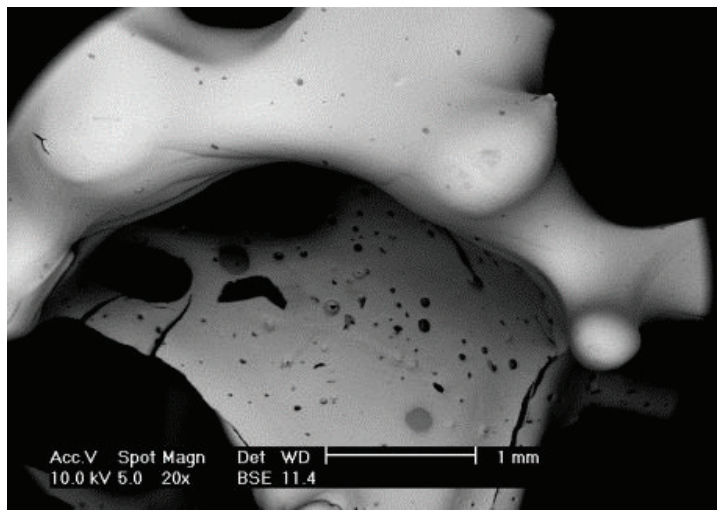

(c)

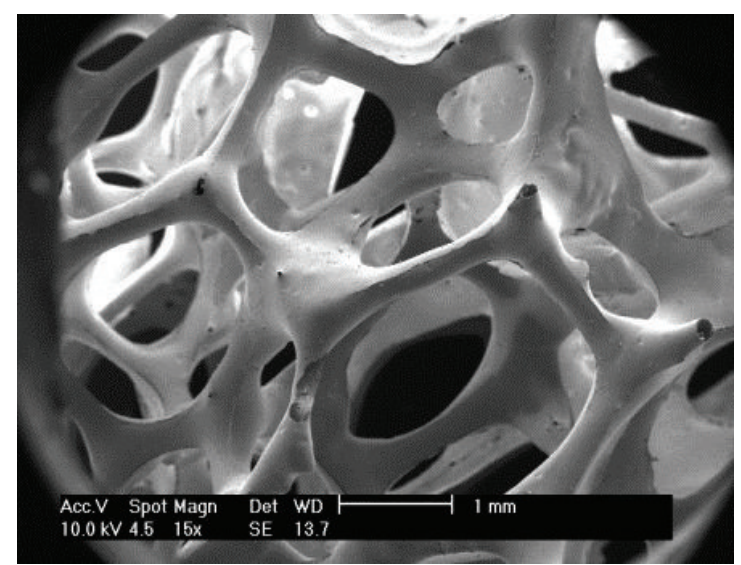

(b)

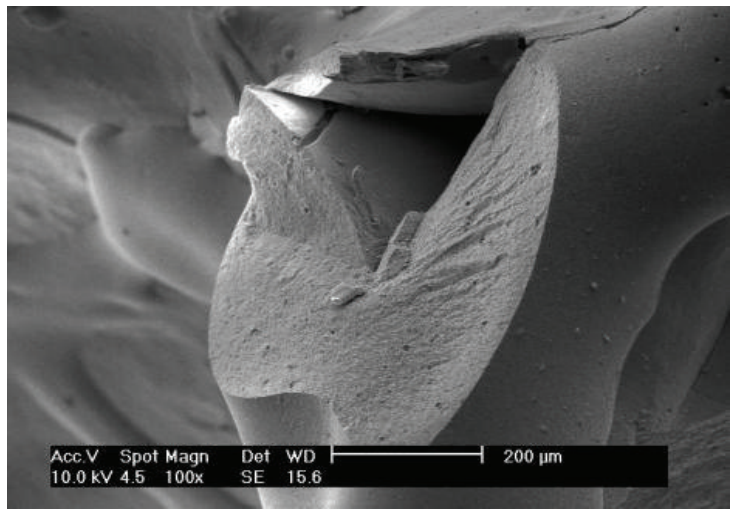

(d)

FIGURE 6: SEM images of YSZ foams: (a) single-coated 3YSZ; (b) single-coated 8YSZ; (c) double-coated 3YSZ; (d) conventional defect left by the organic compounds burning out in a double-coated $3 \mathrm{YSZ}$ foam. 
TABLE 1: Relative density and total porosity values of zirconia foams.

\begin{tabular}{lcccc}
\hline YSZ foams & $\rho_{\text {geometric }}\left(\mathrm{g} / \mathrm{cm}^{3}\right)$ & $\rho_{\text {solid-mat. }}\left(\mathrm{g} / \mathrm{cm}^{3}\right)$ & Relative density, $\rho_{r}$ & Porosity $(\%)$ \\
\hline 3YSZ, double coated & $1.1 \pm 0.1$ & 5.7 & $0.20 \pm 0.10$ & $80.1 \pm 0.1$ \\
3YSZ, single coated & $0.5 \pm 0.3$ & 5.7 & $0.10 \pm 0.30$ & $90.0 \pm 0.3$ \\
8YSZ & $0.4 \pm 0.3$ & 5.8 & $0.08 \pm 0.30$ & $92.0 \pm 0.3$ \\
\hline
\end{tabular}

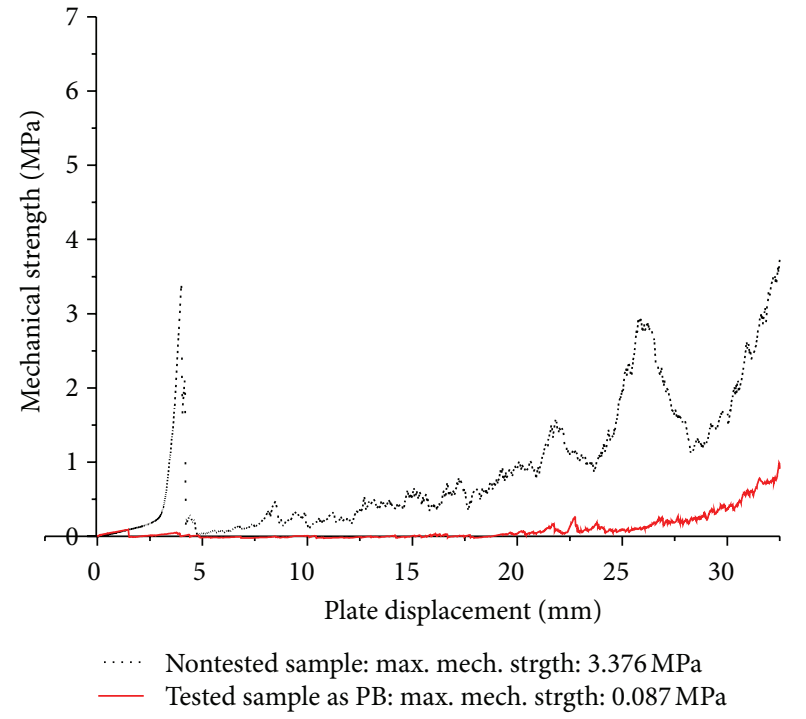

Figure 7: Compression strength of samples before/after the porous burner test.

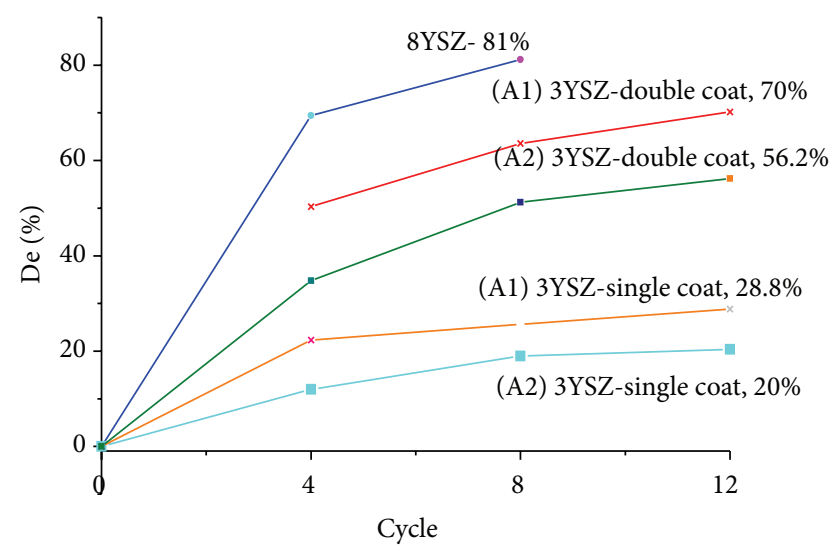

FIGURE 8: Damage done to the YSZ foams owed to a thermal shock test.

3.4. Mechanical Characterization of Foams. The mechanical strength of the double-coated $3 \mathrm{YSZ}$ samples $(2.3 \pm 0.7 \mathrm{MPa})$ is higher than that of the single-coated $3 \mathrm{YSZ}(0.8 \pm 0.3 \mathrm{MPa})$ or $8 Y S Z$ samples $(0.30 \pm 0.04 \mathrm{MPa})$. This fact is owed to the lower density of microstructural defects and thicker walls for the 3 YSZ double-coated samples. The average mechanical strength of samples was $2.3 \pm 0.7 \mathrm{MPa}$ which is comparable to the values found by Elverum et al. [20], in which average mechanical strength was of $1.8 \mathrm{MPa}$.

The compression strength test was also applied to samples which could overcome the burning test. Figure 7 presents
TABLE 2: Values of Young modulus for single/double YSZ samples after thermal shock test.

\begin{tabular}{|c|c|c|}
\hline & $f_{f}(\mathrm{~Hz})$ & $E(\mathrm{GPa})$ \\
\hline \multicolumn{3}{|c|}{ 8YSZ } \\
\hline \multicolumn{3}{|l|}{$\mathrm{A} 1$} \\
\hline W/out cycles & 597 & 0.10 \\
\hline 4 cycles & 330 & 0.03 \\
\hline 8 cycles & 259 & 0.02 \\
\hline \multicolumn{3}{|c|}{ 3YSZ double coated } \\
\hline \multicolumn{3}{|l|}{$\mathrm{A} 1$} \\
\hline W/out cycles & 2373 & 5.07 \\
\hline 4 cycles & 1673 & 2.52 \\
\hline 8 cycles & 1430 & 1.84 \\
\hline 12 cycles & 1296 & 1.51 \\
\hline \multicolumn{3}{|l|}{$\mathrm{A} 2$} \\
\hline W/out cycles & 1721 & 2.25 \\
\hline 4 cycles & 1390 & 1.47 \\
\hline 8 cycles & 1202 & 1.1 \\
\hline 12 cycles & 1139 & 0.98 \\
\hline \multicolumn{3}{|c|}{ 3YSZ single coated } \\
\hline \multicolumn{3}{|l|}{$\mathrm{A} 1$} \\
\hline W/out cycles & 1257 & 0.42 \\
\hline 4 cycles & 1108 & 0.33 \\
\hline 8 cycles & 1084 & 0.32 \\
\hline 12 cycles & 1060 & 0.30 \\
\hline \multicolumn{3}{|l|}{$\mathrm{A} 2$} \\
\hline W/out cycles & 1021 & 0.23 \\
\hline 4 cycles & 958 & 0.20 \\
\hline 8 cycles & 919 & 0.18 \\
\hline 12 cycles & 911 & 0.18 \\
\hline
\end{tabular}

the results obtained of a sample of double-coated 3YSZ that was tested as a porous burner in comparison to the best result obtained for a sample of the same group in Table 2. As can be seen, the mechanical properties of the tested sample were deeply reduced, with a maximum strength of $0.087 \mathrm{MPa}$, corresponding to $2.6 \%$ of the $3.37 \mathrm{MPa}$ of the nontested sample.

Table 2 presents the fundamental frequencies and the corresponding Young moduli of the samples subjected up to 12 thermal shock cycles. As it can be seen, after 12 cycles, the highest Young modulus belonged to the double-coated 3YSZ samples. The 8YSZ samples could withstand just up to 8 cycles.

The total damage done to the structure due to the thermal shock test (DE, Figure 8 ) is lower for the single-coated 3YSZ sample (between 20-28\%), while the double-coated 3YSZ 


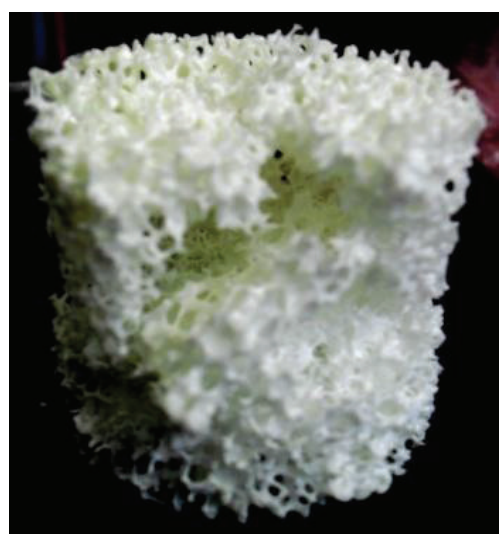

(a)

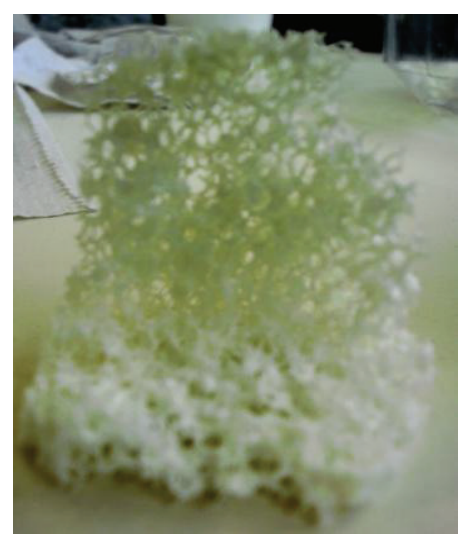

(b)

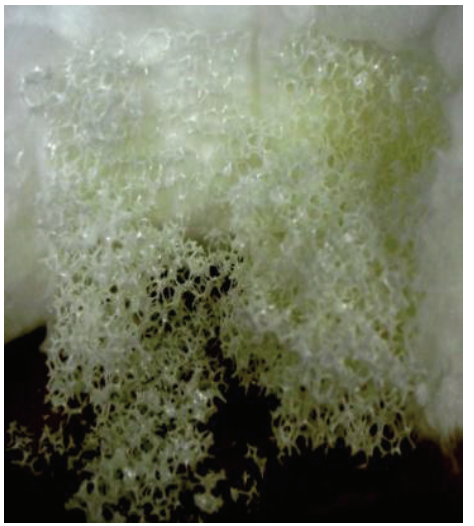

(c)

FIGURE 9: YSZ samples after tested as a porous burner after $6 \mathrm{~h}$ operation: (a) double-coated 3YSZ; (b) single-coated 3YSZ; (c) single-coated 8 YSZ.

samples presented a loss between 55 and 70\%, and the singlecoated 8 YSZ sample had a loss of $80 \%$ related to the original Young modulus.

The fact that the damage done to the single-coated 3YSZ samples was lower than that for the double-coated 3YSZ samples could be explained by the higher porosity that the former samples presented. Higher porosity contributes to relax the thermal stresses that are produced during the thermal shock and also to hinder the growth of microcracks $[31,32]$.

3.5. Porous Burners Performance. Double-coated 3YSZ samples maintained the structural integrity without any evidence of chemical reaction after contact with the flame. The maximum temperature within the burner reached $1600^{\circ} \mathrm{C}$, smaller than the adiabatic flame temperature due to the surface heat transfer to the external ambient. Still, this is a very high temperature for the continuous operation of porous burners [33].

Figure 9 shows YSZ samples after $6 \mathrm{~h}$ operation as porous burners. It can be observed that the external reticulated structure kept its integrity; the internal struts, where the second coating was hindered, were broken. For the singlecoated 3YSZ samples just part of the walls and the inferior base maintained the original structure, as it can be seen in Figure 9(b). The average operational temperature achieved was between 1450 and $1500^{\circ} \mathrm{C}$. The samples of $8 \mathrm{YSZ}$ could not operate at the equivalence ratio of 0.9 , which was then reduced to 0.8 . They presented an average operational temperature between 1300 and $1350^{\circ} \mathrm{C}$, for both standard periods. Figure 9(c) shows one of the tested samples, where it can be seen that the structure was severely destroyed when after contact with the flame.

\section{Conclusions}

The rheological properties of the $8 Y S Z$ suspension were more adequate than those of the 3YSZ suspension, due to the smaller particle size of the 8YSZ powder and the higher amount of binder.
Applying a second coating on to the presintered foams enhanced the structure morphology, hindering the formation of micropores, microcracks, and holes after burning organics. In this case, superior thermomechanical properties were achieved.

The highest thermal shock resistance corresponded to the samples of single-coated 3YSZ, presenting 25\% damage, related to the Young modulus, due to the high porosity. Nevertheless, the samples of double-coated 3YSZ presented the highest Young modulus after the 12 thermal shock cycles.

Only the samples of double-coated 3YSZ withstood satisfactorily the porous burner test. Those samples achieved high work temperatures $\left(1550-1600^{\circ} \mathrm{C}\right)$ during up to $6 \mathrm{~h}$ of operation at the highest equivalence ratio (0.9).

\section{Acknowledgment}

The authors gratefully acknowledge the financial support from the CNPq Foundation, Brazil.

\section{References}

[1] R. C. Catapan, A. A. M. Oliveira, and M. Costa, "Non-uniform velocity profile mechanism for flame stabilization in a porous radiant burner," Experimental Thermal and Fluid Science, vol. 35 , no. 1, pp. 172-179, 2011.

[2] "Nitrogen Oxides (NOx), Why and How they are controlled," Clean Air Technology Center, 1999, http://www.epa.gov/ttn/ catc/dirl/fnoxdoc.pdf.

[3] M. Scheffler and P. Colombo, Cellular Ceramics: Structure, Manufacturing, Properties and Applications, John Wiley \& Sons, New York, NY, USA, 2005.

[4] P. Colombo and H. P. Degischer, "Highly porous metals and ceramics," Materials Science and Technology, vol. 26, no. 10, pp. 1145-1158, 2010.

[5] P. Greil, "Biomorphous ceramics from lignocellulosics," Journal of the European Ceramic Society, vol. 21, no. 2, pp. 105-118, 2001.

[6] T. Inui and T. Otowa, "Catalytic combustion of benzene-soot captured on ceramic foam matrix," Applied Catalysis, vol. 14, pp. 83-93, 1985. 
[7] T. Mizrah, A. Maurer, L. Gauckler, and J. P. Gabathuler, SAE Paper 890172, 1989.

[8] L. Montanaro, Y. Jorand, G. Fantozzi, and A. Negro, "Ceramic foams by powder processing," Journal of the European Ceramic Society, vol. 18, no. 9, pp. 1339-1350, 1998.

[9] P. Colombo and E. Bernardo, "Macro- and micro-cellular porous ceramics from preceramic polymers," Composites Science and Technology, vol. 63, no. 16, pp. 2353-2359, 2003.

[10] M. F. Ashby, "The mechanical properties of cellular solids," Metallurgical Transactions A, vol. 14, no. 9, pp. 1755-1769, 1983.

[11] R. Brezny and J. D. Green, "Structure and properties of ceramics," Materials Science and Technology, vol. 11, pp. 467-516, 1992.

[12] F. Lange and T. K. Miller, "Open cell low density ceramics fabricated from reticulated polymer substrates," Advanced Ceramics Materials, vol. 2, no. 4, pp. 827-831, 1987.

[13] K. Lannguth, "Particle size range as a factor influencing compressibility of ceramic powder," Ceramics International, vol. 21, pp. 237-242, 1995.

[14] V. S. Stunican, R. C. Hink, and S. P. Ray, "Phase equilibriums and ordering in the system zirconia-yttria," Journal of the American Ceramic Society, vol. 61, pp. 17-21, 1988.

[15] X. W. Zhu, D. L. Jiang, S. H. Tan, and Z. Q. Zhang, "Improvement in the strut thickness of reticulated porous ceramics," Journal of the American Ceramic Society, vol. 84, no. 7, pp. 16541656, 2001.

[16] X. Yao, S. Tan, Z. Huang, and D. Jiang, "Effect of recoating slurry viscosity on the properties of reticulated porous silicon carbide ceramics," Ceramics International, vol. 32, no. 2, pp. 137-142, 2006.

[17] S. Y. Gómez, O. Álvarez, J. Escobar, J. B. Rodriguez, C. Rambo, and D. Hotza, "Relationship between rheological behaviour and final structure of $\mathrm{Al}_{2} \mathrm{O}_{3}$ and YSZ foams produced by replica," Advances in Materials Science and Engineering, vol. 2012, Article ID 549508, 9 pages, 2012.

[18] R. Stevens, Zirconia and Zirconia Ceramics, Magnesium Elektron Publication, 2nd edition, 1986.

[19] J. Aguilar and D. Hotza, "Configuraciones alternativas para celdas de combustible de óxido sólido," Revista Latinoamericana de Metalurgia y Materiales, vol. 33, pp. 172-185, 2013.

[20] P. J. Elverum, J. L. Ellzey, and D. Kovar, "Durability of YZA ceramic foams in a porous burner," Journal of Materials Science, vol. 40, no. 1, pp. 155-164, 2005.

[21] L. C. Cossolino and A. Pereira, "Módulos elásticos: visão geral e métodos de caraterização," ATCP Engenharia Física, 2010.

[22] ASTM C1198-96, "Standard test method for dynamic young's modulus, shear modulus and poisson's ratio for advanced ceramics," American Society for Testing Materials, 1996.

[23] F. M. Pereira, A. A. M. Oliveira, and F. F. Fachini, "Asymptotic analysis of stationary adiabatic premixed flames in porous inert media," Combustion and Flame, vol. 156, no. 1, pp. 152-165, 2009.

[24] J. Sun, L. Gao, and J. Guo, "Influence of the Initial pH on the adsorption behaviour of dispersant on nano zirconia powder," Journal of the European Ceramic Society, vol. 19, no. 9, pp. 17251730, 1999.

[25] J. Wang and L. Gao, "Surface and electrokinetic properties of Y-TZP suspensions stabilized by polyelectrolytes," Ceramics International, vol. 26, no. 2, pp. 187-191, 2000.

[26] J. Luo and R. Stevens, "Tetragonality of nanosized 3Y-TZP powders," Journal of the American Ceramic Society, vol. 82, no. 7, pp. 1922-1924, 1999.
[27] M. Filal, C. Petot, M. Mokchah, C. Chateau, and J. L. Carpentier, "Ionic conductivity of yttrium-doped zirconia and the 'composite effect"' Solid State Ionics, vol. 80, no. 1-2, pp. 27-35, 1995.

[28] B. R. Moreno, "Reología de suspensiones cerámicas," Consejo Superior de Investigaciones Científicas, vol. 17, p. 325, 2005.

[29] A. M. Herrera, O. Álvarez, J. Escobar, V. Moreno, and D. Hotza, "Fabrication and characterization of alumina foams for application in radiant porous burners," Revista Matéria, vol. 17, pp. 973-987, 2012.

[30] D. Hotza, "Colagem de folhas cerâmicas," Cerâmica, vol. 43, pp. 157-164, 1994.

[31] V. R. Vedula, D. J. Green, and J. R. Hellmann, “Thermal fatigue resistance of open cell ceramic foams," Journal of the European Ceramic Society, vol. 18, no. 14, pp. 2073-2081, 1998.

[32] L. Shen, M. Liu, X. Liu, and B. Li, "Thermal shock resistance of the porous $\mathrm{Al}_{2} \mathrm{O}_{3} / \mathrm{ZrO}_{2}$ ceramics prepared by gelcasting," Materials Research Bulletin, vol. 42, no. 12, pp. 2048-2056, 2007.

[33] J. R. Howell, M. J. Hall, and J. L. Ellzey, "Combustion of hydrocarbon fuels within porous inert media," Progress in Energy and Combustion Science, vol. 22, no. 2, pp. 121-145, 1996. 

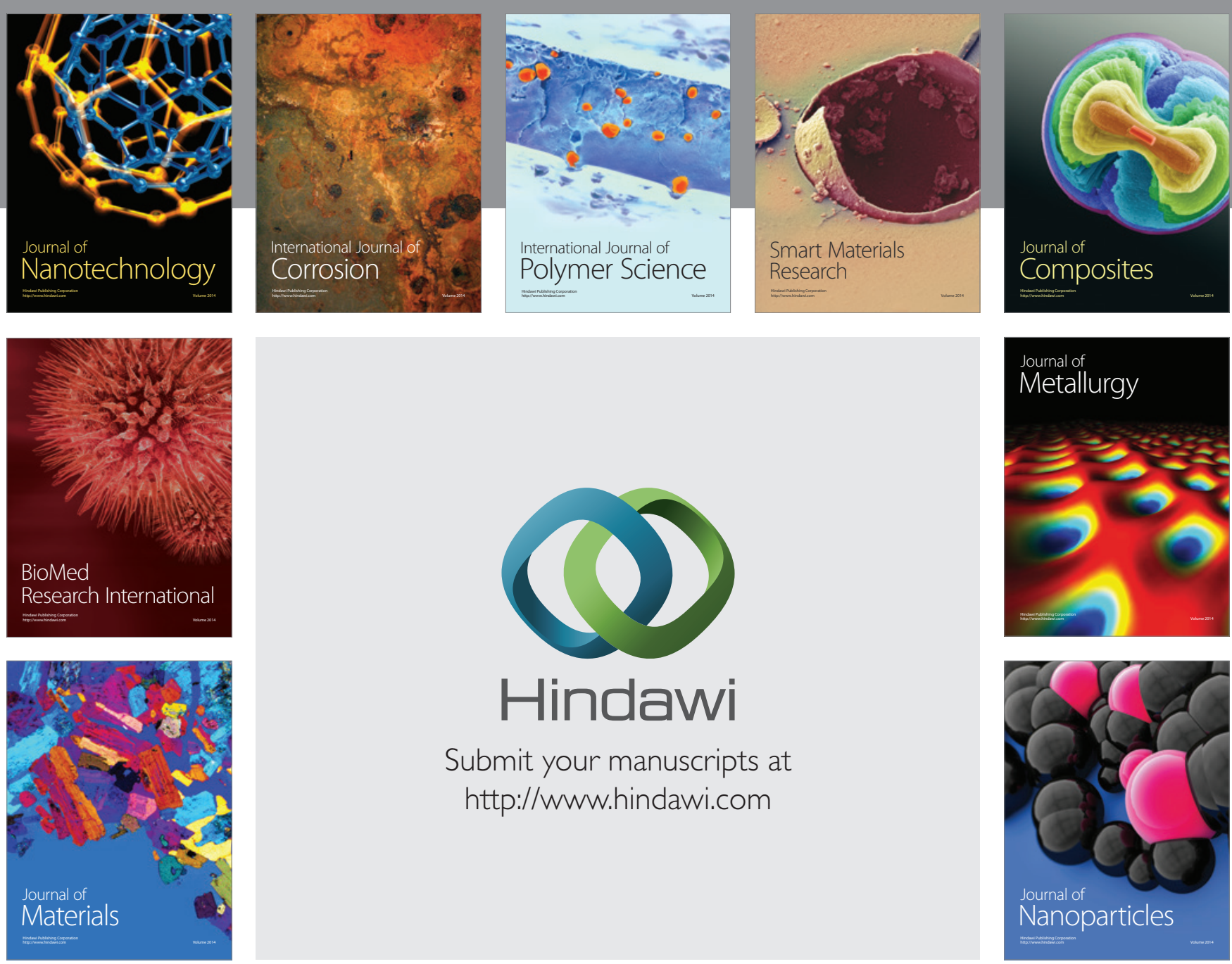

Submit your manuscripts at http://www.hindawi.com
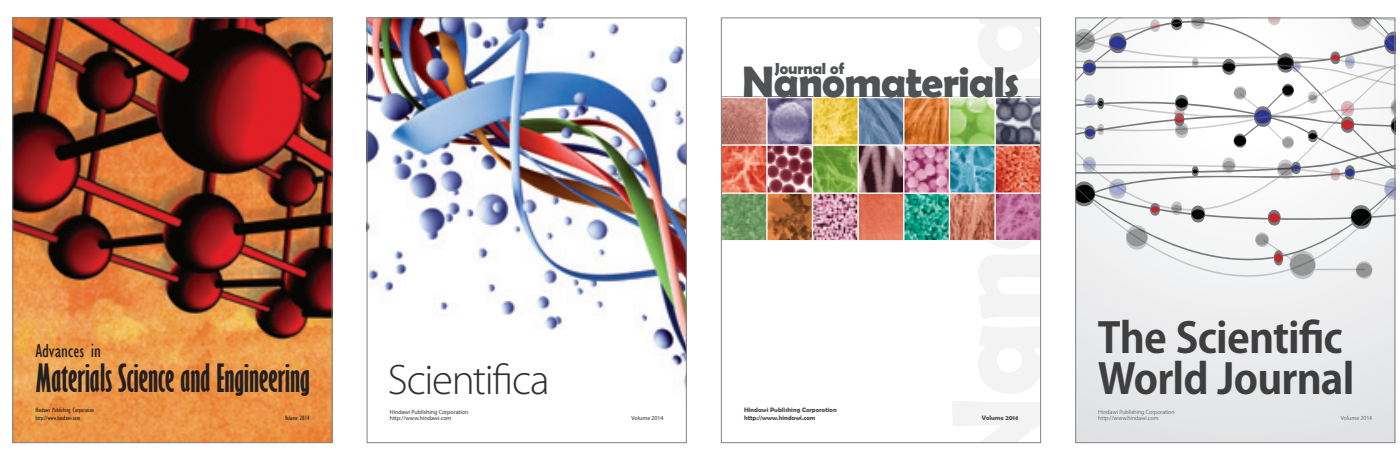

\section{The Scientific World Journal}
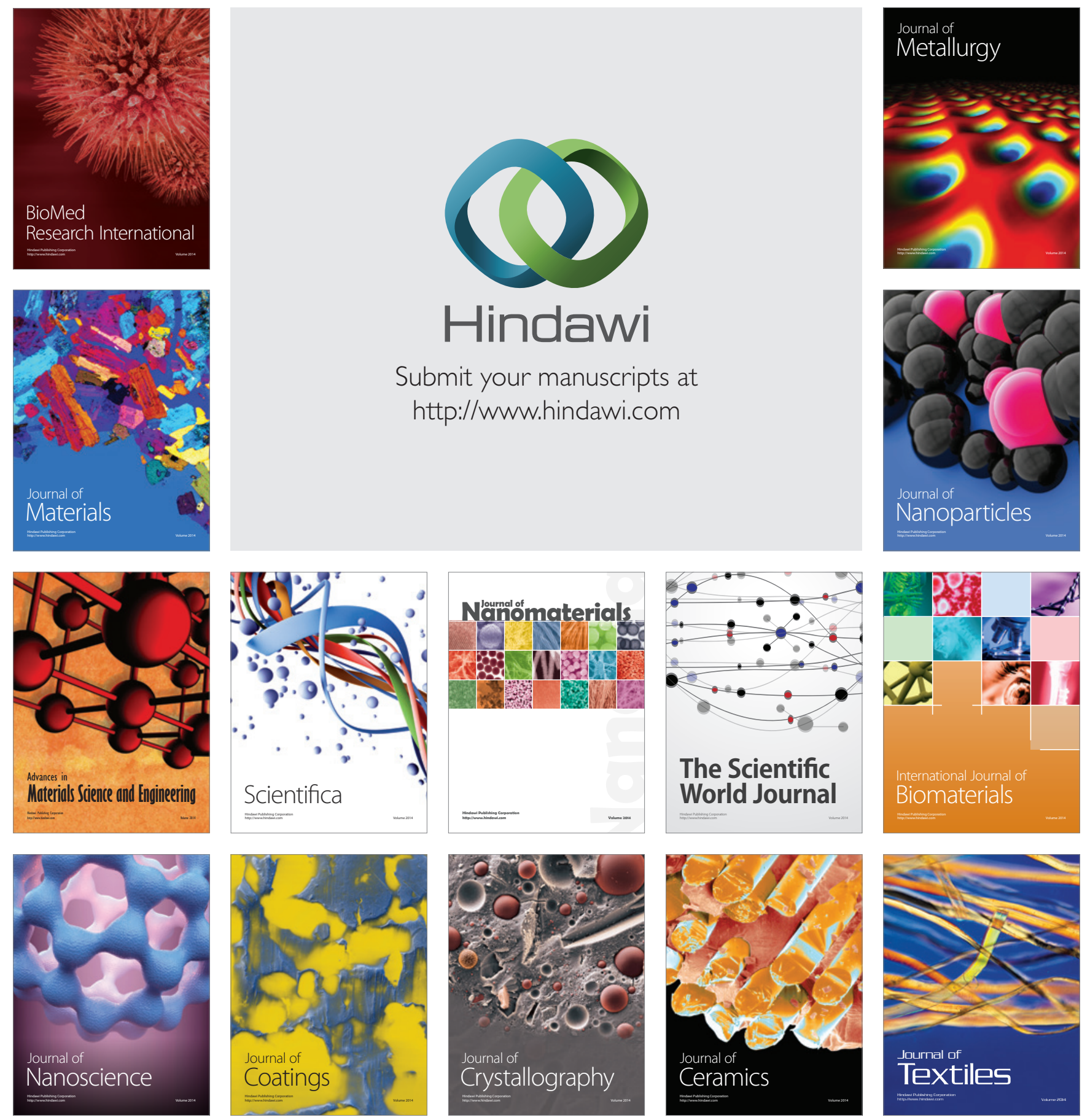